\title{
Crustal thickness along the western Galápagos Spreading Center and the compensation of the Galápagos hotspot swell
}

\author{
J. Pablo Canales ${ }^{a, *}$, Garrett Ito ${ }^{b, c}$, Robert S. Detrick ${ }^{a}$, John Sinton ${ }^{c}$ \\ a Department of Geology and Geophysics, Woods Hole Oceanographic Institution, 360 Woods Hole Road, Woods Hole, MA 02543, \\ USA \\ b Department of Geology, University of California, Davis, CA, USA \\ c Department of Geology and Geophysics, School of Ocean and Earth Science Technology, University of Hawaii, Honolulu, HI, USA
}

Received 1 April 2001; received in revised form 8 July 2002; accepted 10 July 2002

\begin{abstract}
Wide-angle refraction and multichannel reflection seismic data show that oceanic crust along the Galápagos Spreading Center (GSC) between $97^{\circ} \mathrm{W}$ and $91^{\circ} 25^{\prime} \mathrm{W}$ thickens by $2.3 \mathrm{~km}$ as the Galápagos plume is approached from the west. This crustal thickening can account for $\sim 52 \%$ of the $700 \mathrm{~m}$ amplitude of the Galápagos swell. After correcting for changes in crustal thickness, the residual mantle Bouguer gravity anomaly associated with the Galápagos swell shows a minimum of $-25 \mathrm{mGal}$ near $92^{\circ} 15^{\prime} \mathrm{W}$, the area where the GSC is intersected by the WolfDarwin volcanic lineament (WDL). The remaining depth and gravity anomalies indicate an eastward reduction of mantle density, estimated to be most prominent above a compensation depth of 50-100 km. Melting calculations assuming adiabatic, passive mantle upwelling predict the observed crustal thickening to arise from a small increase in mantle potential temperature of $\sim 30^{\circ} \mathrm{C}$. The associated thermal expansion and increase in melt depletion reduce mantle densities, but to a degree that is insufficient to explain the geophysical observations. The largest density anomalies appear at the intersection of the GSC and the WDL. Our results therefore require the existence of compositionally buoyant mantle beneath the GSC near the Galápagos plume. Possible origins of this excess buoyancy include melt retained in the mantle as well as mantle depleted by melting in the upwelling plume beneath the Galápagos Islands that is later transported to the GSC. Our estimate for the buoyancy flux of the Galápagos plume $\left(700 \mathrm{~kg} \mathrm{~s}^{-1}\right)$ is lower than previous estimates, while the total crustal production rate of the Galápagos plume (5.5 $\mathrm{m}^{3} \mathrm{~s}^{-1}$ ) is comparable to that of the Icelandic and Hawaiian plumes.
\end{abstract}

(c) 2002 Elsevier Science B.V. All rights reserved.

Keywords: Galapagos Rift; crust; hot spots; swells; plumes; mid-ocean ridges

\section{Introduction}

About $30 \%$ of the ocean floor is occupied by

\footnotetext{
* Corresponding author. Tel.: +1-508-289-2893;

Fax: +1-508-457-2150.

E-mail address: jpcanales@whoi.edu (J.P. Canales).
}

depth anomalies (swells) that correlate with gravity anomalies and hotspot volcanism [1] likely to originate from mantle plumes. Understanding how hotspot swells are formed and sustained over time will provide insight into the dynamics of plume-lithosphere interaction and transfer of energy from the deep mantle to the Earth's surface. Studies of mid-plate swells (e.g. [2,3-6]) sug- 
gest that these features are supported by a combination of buoyancy by an ascending mantle plume and lithospheric density anomalies of thermal and/or chemical origin. The primary sources contributing to swell uplift are [7]: (1) thermal reheating of the lithosphere by magma injection; (2) thermal expansion of hot plume material ponding at the base of the lithosphere; (3) compositional buoyancy of the residual swell root depleted by melt extraction; and (4) crustal thickening by hotspot magmatism. However, the relative importance of each of them remains debatable.

The importance of buoyancy caused by anomalously hot mantle has been tested using heat flow measurements, but the results have been inconclusive [3-5,8]. However, anomalously low seismic velocities support the possibility of elevated mantle temperatures beneath some hotspots $[9,10]$. Another potentially important source of buoyancy may arise from depletion of melt from the mantle. Partial melting of fertile mantle results in a lighter, depleted residue by preferential extraction of heavier elements such as iron and consumption of denser phases such as garnet $[11,12]$. The correlation between swell topography and volcano volume in Hawaii [7] argues for depletion as the primary source of support for the Hawaiian swell (although numerical modeling suggests that depletion plays a secondary role [13]). As depletion would increase the seismic velocity of the residue [12], the observed elevated mantle seismic velocities beneath some hotspot swells [14] also support models with depleted swell roots. While the relative importance of thermal versus compositional mantle buoyancy remains controversial, there is strong evidence that both effects are important. Magmatic underplating and crustal thickening $[15,16]$ may play an important role in supporting some hotspot swells, as in the case of the Marquesas hotspot swell [6].

The study of swells associated with mantle plumes proximal to mid-ocean ridges can provide additional constraints on the structure of oceanic swells. Plume-related mantle thermal anomalies across the swell may alter crustal production along the nearby mid-ocean ridge. Higher mantle temperatures will result in larger melt production by adiabatic mantle upwelling [17]. Therefore, the contribution of the thermal anomaly to swell uplift can be evaluated from melt production indicators such as crustal thickness along the spreading center. An ideal case of an oceanic swell and near-ridge hotspot is the Galápagos plume-ridge system (e.g. [18]).

The Galápagos hotspot swell encompasses a large portion of the Galápagos Spreading Center (GSC) in the eastern equatorial Pacific (Fig. 1a). The GSC bisects the swell in an east-west direction, separating the Cocos and Nazca plates at an intermediate full rate that increases from $47 \mathrm{~mm}$ $\mathrm{yr}^{-1}$ near $97^{\circ} \mathrm{W}$ to $63 \mathrm{~mm} \mathrm{yr}^{-1}$ at $86^{\circ} \mathrm{W}$ [19]. The large morphological variations observed along the GSC [20] suggest along-axis changes in magma supply related to the nearby Galápagos plume. Dominant volcanic features include the Cocos and Carnegie ridges, the Galápagos Archipelago and platform, and the Wolf-Darwin lineament (WDL), a volcanic chain extending between the Galápagos platform and the GSC. All these features reflect the activity and evolution of the Galápagos hotspot and its interaction with the GSC.

Previous studies of the mantle density structure beneath the GSC supporting the Galápagos swell were based on bathymetry and gravity observations [21]. In this paper we use wide-angle and multichannel seismic (MCS) data to constrain crustal thickness variations along the western GSC, from which we then infer mantle temperature variations beneath the GSC. Additional modeling of topography and gravity data provides constraints on the anomalous density distribution across the Galápagos swell. The integrated interpretation of all the geophysical data allows us to discriminate between thermal and chemical anomalies, and quantify their importance in compensating the Galápagos swell.

\section{Seismic crustal thickness along the western GSC}

As part of the G-PRIME project (Galápagos Plume-Ridge Interaction Multidisciplinary Experiment), wide-angle and MCS data were collected along the GSC between $97^{\circ} \mathrm{W}$ and $91^{\circ} 20^{\prime} \mathrm{W}$ [22] (Fig. 1b). In this paper we used a subset of these data to constrain the long-wave- 
length variation in crustal thickness along the western GSC.

\subsection{Wide-angle seismic refraction}

\subsubsection{Data}

Three axis-parallel wide-angle seismic profiles
(Gala-1, Gala-2 and Gala-3; Fig. 1b) were shot along the western GSC. The seismic source was the R/V Maurice Ewing's 143-1 air gun array towed at a depth of $8 \mathrm{~m}$, with a shot interval of $210 \mathrm{~s}$ at a nominal speed of 4.5 knots. Shot locations were obtained from shipboard Global Positioning System (GPS) positions corrected for the
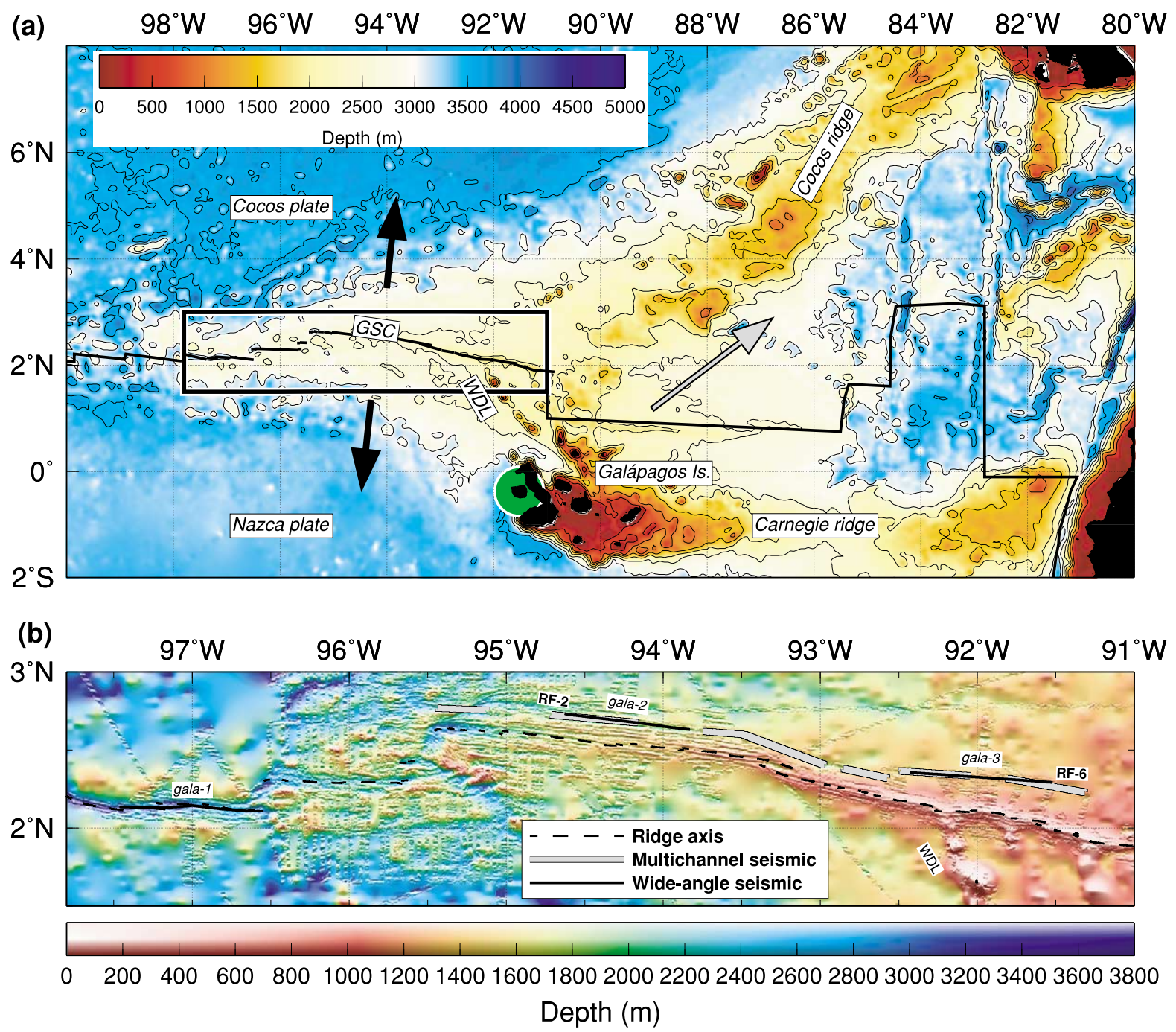

Fig. 1. (a) Bathymetry map of the Galápagos region [53]. GSC is the Galápagos Spreading Center and WDL is the Wolf-Darwin lineament. Contours every $500 \mathrm{~m}$. The Galápagos swell is roughly marked by the shallow depths $(<3000 \mathrm{~m})$ extending between $\sim 97^{\circ} \mathrm{W}$ and $85^{\circ} \mathrm{W}$. The green circle marks the present location of the Galápagos hotspot beneath Fernandina [54]. Black arrows show the seafloor spreading direction and the gray arrow shows the migration of the ridge in a hotspot reference frame at a rate of $47 \mathrm{~mm} / \mathrm{yr}$ [55]. (b) Bathymetry map of the study area (western section of the GSC). Bathymetry data include global bathymetry derived from satellite altimetry data [53] and multibeam bathymetry (National Geophysical Data Center, Canales et al. [20] and Detrick et al. [22]). Dashed lines mark the location of the spreading axis, thin solid lines are wide-angle seismic refraction profiles (labeled Gala-1, 2 and 3), and gray lines are multichannel seismic profiles (labeled RF-2 and RF-6 in Fig. 4). 
distance between the GPS antenna and the air gun array. The shots were recorded by ocean bottom hydrophones (OBHs). Locations of the instruments on the seafloor were determined from the shot position and water-wave travel times using a Monte Carlo simulation [23]. The water depth at the relocated position of the instruments was taken from the Hydrosweep multibeam bathymetry.
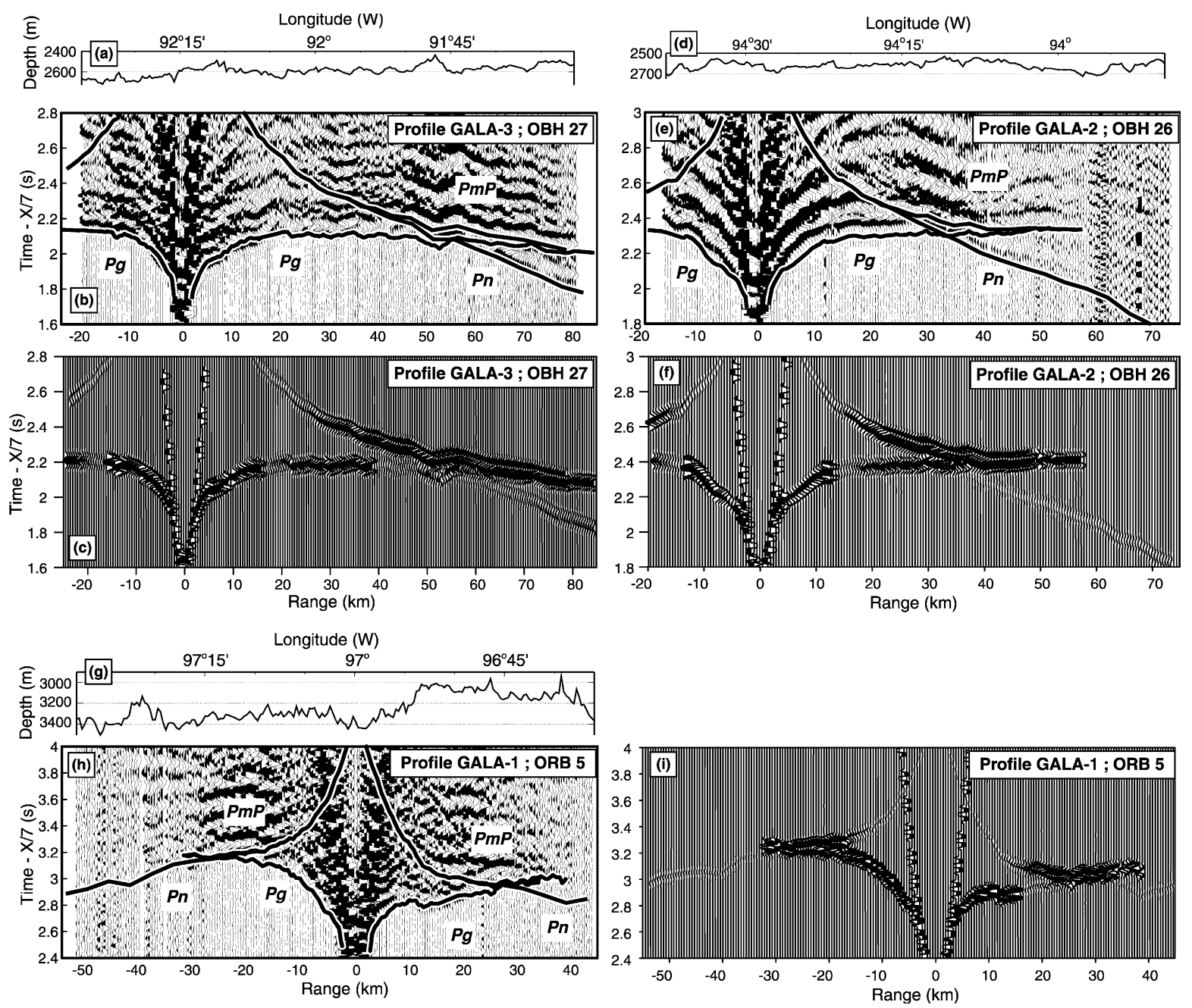

Fig. 2. (a) Bathymetry along profile Gala-3. (b) Wide-angle seismic record section from instrument OBH-27, located at the western end of profile Gala-3. Travel time is reduced to $7 \mathrm{~km} \mathrm{~s}^{-1}$. Solid lines are predicted travel time curves by the preferred 1-D velocity model (Fig. 3b) for crustal arrivals $(P g)$, Moho reflections $(P m P)$ and upper mantle refractions $(P n)$. (c) Synthetic record section predicted by the preferred 1-D velocity model (Fig. 3b). (d-f) same as (a-c) for instrument OBH-26, located at the western end of profile Gala-2. (g-i) same as $(\mathrm{a}-\mathrm{c})$ for instrument ORB-5, located at the center of profile Gala-1. 
evenly spaced every $15 \mathrm{~km}$. All of the instruments returned data with high signal-to-noise ratio. The maximum shot-receiver aperture was $80 \mathrm{~km}$, which allowed recording crustal refractions $(P g)$, Moho reflections $(P m P)$ and upper mantle reflections $(P n)$. Fig. 2b shows an example of a seismic record section recorded at Gala-3. The $P g$ phase is clearly observed as first arrival at ranges $<55$ $\mathrm{km}$, the $P m P$ phase is observed as a high-amplitude, secondary arrival between 30 and $80 \mathrm{~km}$ ranges, and the $P n$ phase is observed as first arrival at ranges $>55 \mathrm{~km}$.

The $90 \mathrm{~km}$ long profile Gala-2 was centered at $94^{\circ} 15^{\prime} \mathrm{W}$ (Figs. $1 \mathrm{~b}$ and $2 \mathrm{~d}$ ) $15 \mathrm{~km}$ to the north of the spreading axis, which is characterized by a rough morphology transitional between axial high and valley [20]. The profile was recorded with five OBHs evenly spaced every $15 \mathrm{~km}$. All of them returned data with high signal-to-noise ratio, but a clock failure in the middle instrument prevented us from using the data from this $\mathrm{OBH}$. The maximum shot-receiver aperture was $75 \mathrm{~km}$. Fig. 2e shows a record section representative of this profile with the identified seismic phases.

The $95 \mathrm{~km}$ long profile Gala-1 was centered at $97^{\circ} \mathrm{W}$ (Figs. $1 \mathrm{~b}$ and $2 \mathrm{~g}$ ) along a deep axial valley similar to those found at slow-spreading ridges like the Mid-Atlantic Ridge (MAR). This site will serve as our reference, unperturbed crustal model since bathymetry and geochemical data indicate that this part of the GSC is not influenced by the Galápagos plume [22]. The profile was located in near-zero age crust because previous studies (e.g. $[24,25])$ show that at ridge segments with axial-valley morphology, the oceanic crust acquires its full thickness at or very near the spreading axis. Five OBHs spaced every $19 \mathrm{~km}$ were deployed along Gala-1, but only the three easternmost instruments returned good-quality data. Fig. $2 \mathrm{~h}$ shows a record section representative of this profile with the identified seismic phases.

\subsubsection{Modeling and results}

To obtain the crustal structure at the three sites we modeled $P g, P m P$ and $P n$ travel times using a forward ray-tracing algorithm [26]. The travel time picks of the $P g, P m P$ and $P n$ phases were handpicked, with an estimated uncertainty of 20, 30 and $25 \mathrm{~ms}$, respectively. In addition to modeling the travel times, we also computed synthetic seismograms [26] to ensure that the preferred models predict relative amplitudes consistent with the observations.

Inspection of the $P g$ travel time against shotreceiver offset (Fig. 3a) shows that $P g$ picks along profiles Gala-3 and Gala-2 have very little variability $(<150 \mathrm{~ms})$ for a given offset. This suggests that the crustal velocity structure along these profiles is basically one-dimensional (1-D), with no significant lateral variability along the profiles. We therefore modeled the wide-angle travel times to obtain the best 1-D structure and averaged crustal thickness at each of the profiles. Modeling the two-dimensional structure along the profiles would add very little information to our objective of finding the long-wavelength variation in crustal thickness between the three sites. In contrast, $P g$ picks from profile Gala-1 show larger variability (Fig. 3a), suggesting larger lateral velocity variations. To be consistent with the modeling approach in the three profiles, we obtained the averaged 1-D structure in two distinct domains (east and west of $96^{\circ} 55^{\prime} \mathrm{W}$ ) along profile Gala- 1 .

The preferred 1-D structures and their estimated uncertainties (see Appendix) are shown in Fig. 3b,c, respectively. Travel times predicted by our preferred models for each of the representative instruments are shown in Fig. 2c,e,h and the synthetic seismograms are shown in Fig. 2c,f,i. We find little difference in crustal velocities between Gala-2 and Gala-3, which are similar to those of the EPR. In contrast, we find lower crustal velocities at Gala-1, similar to those found in the slow-spreading MAR, probably reflecting a more tectonized and fractured crust. Averaged crustal thicknesses along each profile (Fig. 3b) show a progressive increase from west to east: $5.60 \mathrm{~km}$ at Gala-1, $5.90 \mathrm{~km}$ at Gala-2, and 7.45 $\mathrm{km}$ at Gala-3. The increase in crustal thickness is consistent with the observation that the crossover distance between $P g$ and $P n$ increases from $25 \mathrm{~km}$ at Gala-1 (Fig. 2h) to $32 \mathrm{~km}$ at Gala-2 (Fig. 2e) and to $55 \mathrm{~km}$ at Gala-3 (Fig. 2b). Although the small differences in crustal age among the three profiles may account for some of the differences in 
crustal velocity structure (e.g. [27]), they cannot explain the variation in crustal thickness (e.g. [28]).

\subsection{MCS reflection}

While refraction experiments provide accurate crustal velocity and thickness information at three localized regions along the GSC, MCS reflections from the Moho provide crustal thickness constraints between the refraction experiments along $\sim 370 \mathrm{~km}$ of the GSC (Fig. 1b). The MCS survey included six axis-parallel lines $15-30 \mathrm{~km}$ north of the ridge axis on mature crust. Energy from a 72-1 air gun array was recorded with a $6.1 \mathrm{~km}$ long, 480-channel, digital streamer every $\sim 15$ s to obtain 80-fold common mid-point (CMP) gathers. In the CMP gathers, reflections from the Moho appeared as a nearly flat arrival, typically extending from zero to $3.5-5 \mathrm{~km}$ shot-receiver offsets. Prior to stacking, traces with offsets less than $0.5-1.5 \mathrm{~km}$ were muted to minimize coherent noise with moveout larger than Moho. We then corrected for normal moveout and stacked the CMPs.

We confidently image Moho along $\sim 80 \%$ of the stacked MCS sections. In the westernmost end of the survey Moho appears as a relatively weak, flat lying reflector at $\sim 2.0 \mathrm{~s}$ two-way travel time (TWTT) below the seafloor (Fig. 4a). The sub-seafloor TWTT to Moho increases to the east, reaching $\sim 2.5 \mathrm{~s}$ near $92^{\circ} \mathrm{W}$ (Fig. $4 \mathrm{~b}$ ), where the Moho reflection is the strongest. To compute crustal thickness from TWTT to Moho we converted the velocity-depth profiles from each of the three refraction experiments (Fig. 3b) to velocityTWTT profiles and assigned each profile to the center of the associated refraction line. We then used a cubic spline to interpolate velocities horizontally between the refraction line centers at each CMP location. The TWTT to Moho picks were then converted to crustal thickness from the interpolated velocity-TWTT profiles.

Fig. 5b shows crustal thicknesses along the
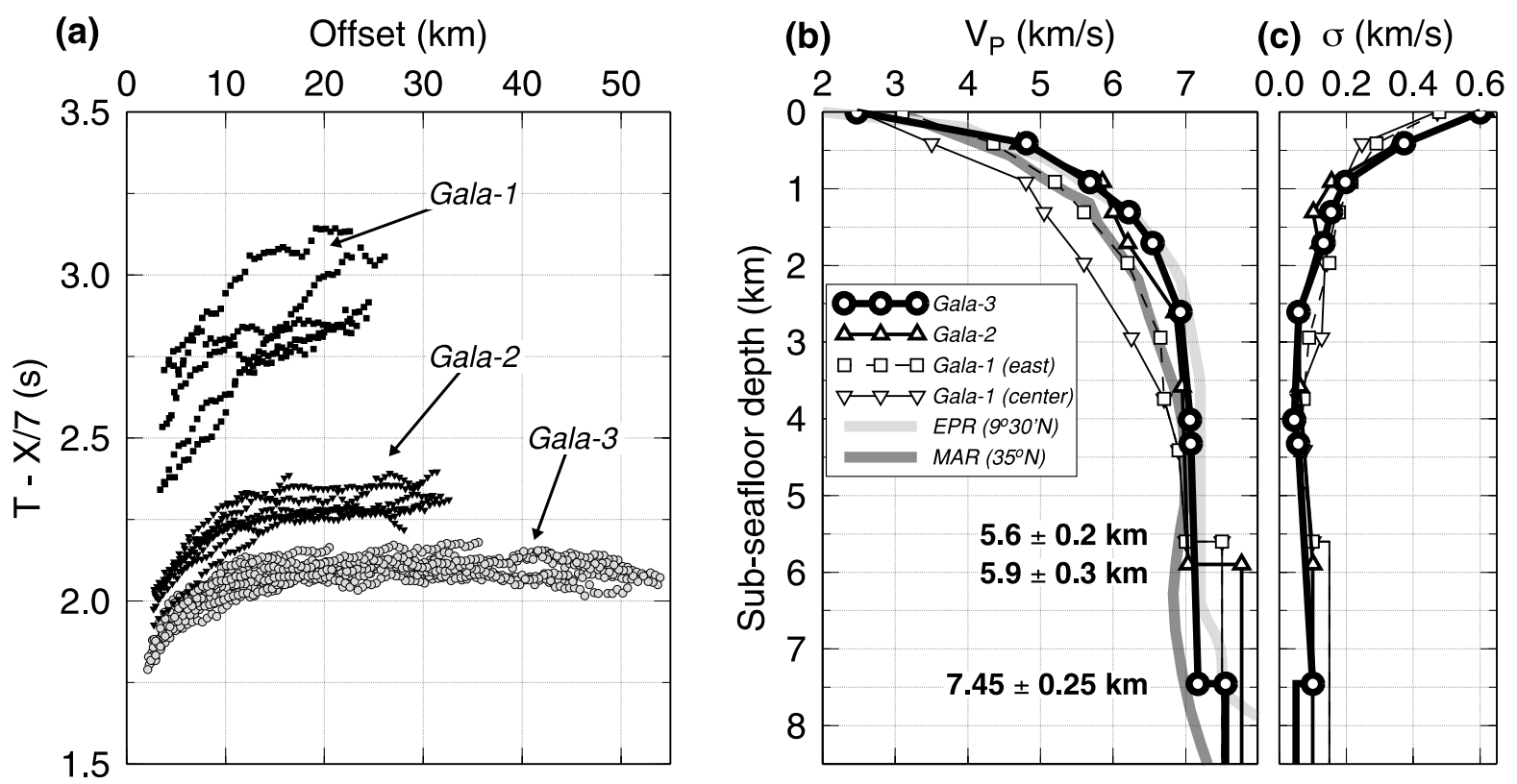

Fig. 3. (a) $P g$ travel time picks for the OBHs along profiles Gala-1 (squares), Gala-2 (triangles) and Gala-3 (circles). Note that picks for Gala-2 and Gala-3 show very little travel time variability for a given shot-receiver offset, suggesting that the crustal velocity structure at these sites is basically 1-D. Instead, picks for Gala-1 show larger variability due to a more heterogeneous crustal structure. (b) Preferred 1-D velocity models for the three wide-angle seismic profiles. Crustal thicknesses are indicated. Velocity structures representative of fast-spreading (EPR) [34] and slow-spreading (MAR) [24] ridges are shown for comparison. (c) Estimated uncertainties of the velocity models. See Appendix for details. 


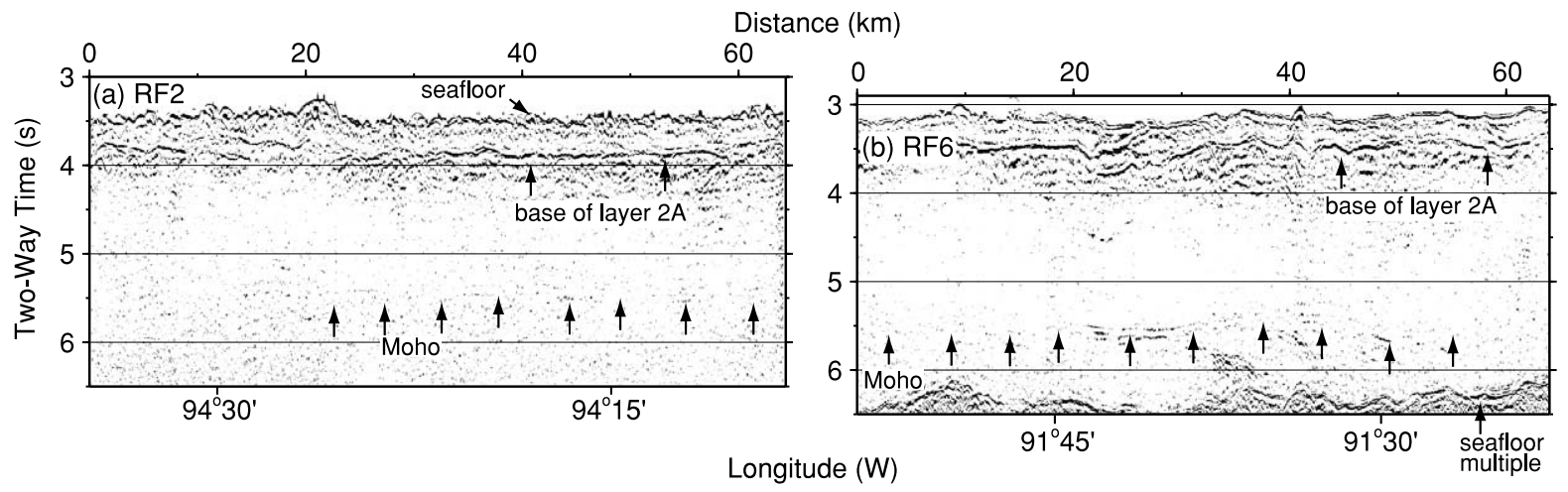

Fig. 4. Stacked multichannel seismic section along profiles (a) RF-2 and (b) RF-6. See Fig. 1b for location. Prominent sub-seafloor reflectors are interpreted as the base of layer 2A and the Moho. Note that both panels are roughly aligned with the seafloor reflection to enhance the differences in crustal TWTT to the Moho reflection between both profiles. The Moho in RF-2 is at $\sim 2 \mathrm{~s}$ TWTT below the seafloor, while at RF-6 it is deeper $(\sim 2.3 \mathrm{~s}$ TWTT $)$.

GSC derived from both the MCS and refraction data. Consistency between the two datasets is demonstrated by the similarity in crustal thickness measurements where the two datasets overlap (i.e. Gala-2 and Gala-3). The MCS picks show shortwavelength $(<50 \mathrm{~km})$ undulations in crustal thickness typically $\pm 0.5 \mathrm{~km}$ in amplitude. Some of these undulations may arise from seafloor roughness that introduces some uncertainty in the identification of the Moho reflection. On the other hand, some of these undulations likely reflect true structural variations, in particular east of $92^{\circ} 30^{\prime} \mathrm{W}$ where the Moho reflection is high in amplitude and seafloor topography is smooth. For our purpose of determining the origin of the Galápagos swell, however, we will ignore these short-wavelength variations and focus only on the longest-wavelength regional variation. To produce a regional, smooth crustal thickness model we use a third-order polynomial that fits the MCS and refraction results in a least-squares sense. This regional crustal model shows minimum crustal thicknesses of $\sim 5.6 \mathrm{~km}$, closely matching the refraction results at Gala-1. This reference value is consistent with mean values of crustal thickness in fast-spreading crust (e.g. [28]), and slow-spreading crust averaged along individual ridge segments [25]. The maximum crustal thickness approaches $8.0 \mathrm{~km}$ at the eastern end of the survey. We thus find a total thickening of the crust by $\sim 2.3 \mathrm{~km}$, an increase by $\sim 40 \%$ of the minimum crustal thickness (Fig. 5b).

\section{Compensation of the Galápagos swell}

\subsection{Depth anomaly}

Hydrosweep multibeam bathymetry acquired during the G-PRIME cruise has allowed us for the first time to map continuously the ridge crest along the GSC between $97^{\circ} 50^{\prime} \mathrm{W}$ and $90^{\circ} 50^{\prime} \mathrm{W}$ (Fig. 1b). Along the western section of the GSC the axial depth shoals from west to east by $1800 \mathrm{~m}$ (Fig. 5a). While part of this change in axial depth corresponds to the bathymetry anomaly of the Galápagos swell, a significant part of it is probably related to changes in axial morphology. Lithospheric stresses, which are controlled by the thermal state of the lithosphere, are responsible for the origin of mid-ocean ridge topography such as axial valleys and highs (e.g. [29,30]).

We use a two-dimensional filtering approach to remove from the axial depth profile the topography variations that result from changes in axial morphology. Low-pass filtering the bathymetry with cutoff wavelengths $(\lambda)$ smaller than $85 \mathrm{~km}$ results in swell amplitudes that decrease progressively as $\lambda$ increases. In contrast, for $\lambda>85 \mathrm{~km}$ the swell amplitude remains constant indepen- 
(a)

$\mathrm{km}$ from ridge axis

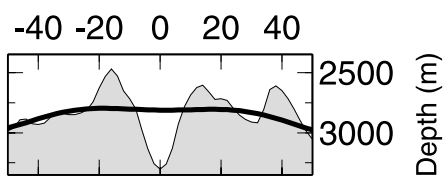

$\mathrm{km}$ from ridge axis

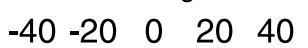

$\begin{array}{lllll}-40 & -20 & 0 & 20 & 40\end{array}$
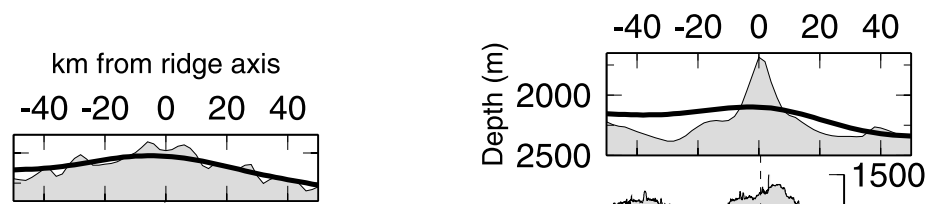

2500

1500

2000

2500

政

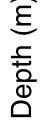

3500
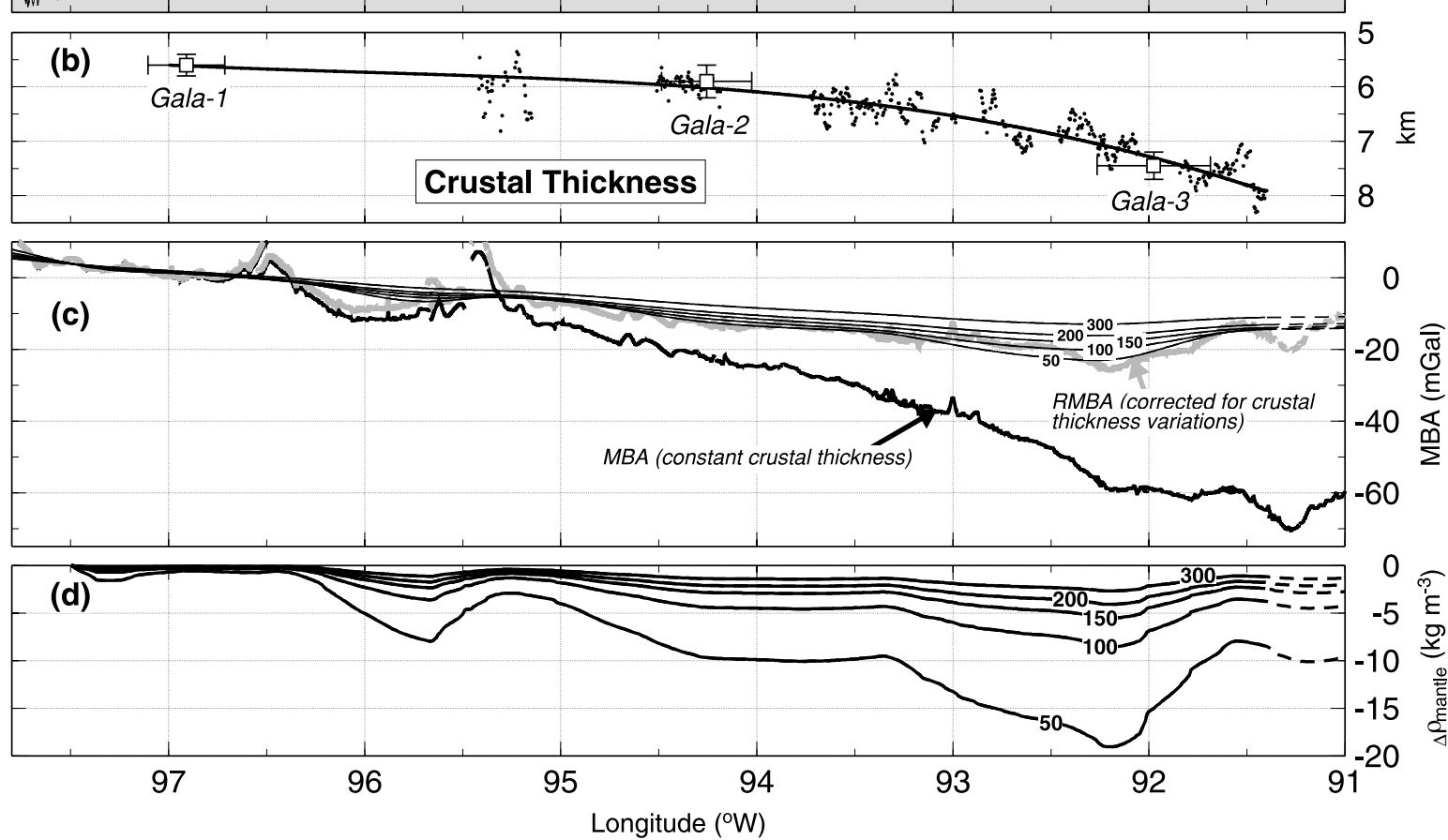

Fig. 5. (a) Axial depth along the GSC. Thick solid line is the axial depth taken from the low-pass filtered bathymetry (cutoff wavelength of $85 \mathrm{~km}$ ), interpreted as the swell topography. Dashed line shows the predicted topography anomaly due to variations in crustal thickness, calculated from Eq. 1. Insets show the cross-axis topography (filtered and unfiltered) at three locations with distinct axial morphology. In areas characterized by axial-valley morphology (west of $95^{\circ} 30^{\prime} \mathrm{W}$ ), filtering removes the elevated shoulders and the deepening of the valley floor. Where an axial high is present (east of $92^{\circ} 40^{\prime} \mathrm{W}$ ), filtering attenuates the amplitude of the high. And where the morphology is a transition between axial high and valley, filtering does not significantly change the axial depth. (b) Crustal thickness along the GSC from the multichannel seismic data (solid circles). The open squares are the crustal thickness measurements from the wide-angle profiles. The solid line is a smooth crustal thickness profile derived from both the MCS and wide-angle observations. (c) Thick solid line is the mantle Bouguer gravity anomaly (MBA) along the GSC computed assuming constant crustal thickness (see text for details). The gray line is the RMBA calculated using the smooth Moho profile in (b) (see text for details). Thin solid lines are gravity anomalies produced by the mantle density variations shown in (d) for different compensation depths (labels in $\mathrm{km}$ ). (d) Along-axis variations in mantle density inferred from the isostasy model (Eq. 2, see text for details), for different values of the compensation depth (labels in km). Dashed portions of the curves in (c) and (d) are extrapolations where there are no crustal thickness constraints. 
dently of $\lambda$. As a first-order approximation, we consider that a low-pass filter with $\lambda=85 \mathrm{~km}$ effectively removes the contribution of the axial topography while preserving the longer-wavelength anomaly associated with the swell. The insets in Fig. 5a illustrate the effect of the filtering on cross-axis bathymetry. We find that $\sim 60 \%$ of the observed variations in axial depth is related to changes in axial morphology. The amplitude of the bathymetry swell along the GSC is therefore given by the filtered axial depth (Fig. 5a), which has a maximum elevation of $\sim 700 \mathrm{~m}$ near $91^{\circ} \mathrm{W}$.

We calculate the topography anomaly related to crustal thickness variations, $\Delta H_{\mathrm{c}}$, by assuming local Airy isostasy (see Table 1 for definitions):

$\Delta H_{\mathrm{c}}=\frac{\Delta \rho_{\mathrm{mc}}}{\Delta \rho_{\mathrm{mw}}} \cdot \Delta C$
Fig. 5a shows that $\Delta H_{\mathrm{c}}$ underestimates the observed swell amplitude. On average, east of $94^{\circ} \mathrm{W}$ crustal thickness variations support $52 \pm 11 \%$ of the depth anomaly (although locally near $91^{\circ} 30^{\prime} \mathrm{W}$ it can be as much as $80 \%$ ). This indicates that variations in crustal thickness cannot be the only source of support for the Galápagos swell; an eastward decrease in mantle density is also required.

\subsection{Gravity anomaly}

Gravity data were acquired continuously during the G-PRIME cruise using the R/V Ewing's Bell Aerospace BGM-3 gravity meter. Free air anomalies (FAA) were obtained from the total gravity field measurements after Eötvos and instrumental drift corrections. FAA was reduced

Table 1

Notation

\begin{tabular}{|c|c|c|}
\hline Variable & Definition [units] & Value \\
\hline$A_{\mathrm{c}}$ & cross-sectional area of the excess crust $\left[\mathrm{m}^{2}\right]$ & $8.9 \times 10^{8 \mathrm{a}}$ \\
\hline$A_{\mathrm{s}}$ & cross-sectional area of the swell (mantle contribution) $\left[\mathrm{m}^{2}\right]$ & $1.8 \times 10^{8 \mathrm{a}}$ \\
\hline$C$ & crustal thickness $[\mathrm{m}]$ & \\
\hline$C_{\mathrm{p}}$ & heat capacity $\left[\mathrm{J} \mathrm{kg}^{-1} \mathrm{~K}^{-1}\right]$ & 1256 \\
\hline$\Delta C$ & crustal thickness variation $[\mathrm{m}]$ & \\
\hline $\mathrm{d} F / \mathrm{d} P$ & melt productivity $\left[\% \mathrm{GPa}^{-1}\right]$ & \\
\hline $\mathrm{d} T /\left.\mathrm{d} P\right|_{\mathrm{adb}}$ & slope of the adiabat $\left[{ }^{\circ} \mathrm{C} \mathrm{GPa}^{-1}\right]$ & 10 \\
\hline $\mathrm{d} T /\left.\mathrm{d} P\right|_{\text {sol }}$ & slope of the solidus $\left[{ }^{\circ} \mathrm{C} \mathrm{GPa}^{-1}\right]$ & 130 \\
\hline$F$ & melt fraction & \\
\hline$H_{\mathrm{f}}$ & heat of fusion $\left[\mathrm{J} \mathrm{kg}^{-1}\right]$ & $754 \times 10^{3}$ \\
\hline$\Delta H$ & swell topography $[\mathrm{m}]$ & \\
\hline$\Delta H_{\mathrm{c}}$ & swell topography due to crustal thickness variations [m] & \\
\hline$P$ & pressure $[\mathrm{GPa}]$ & \\
\hline$T$ & temperature $\left[{ }^{\circ} \mathrm{C}\right]$ & \\
\hline$T_{0}^{\mathrm{sol}}$ & intercept of the solidus $\left[{ }^{\circ} \mathrm{C}\right]$ & 1100 \\
\hline$U$ & full spreading rate $\left[\mathrm{mm} \mathrm{yr}^{-1}\right]$ & 54 \\
\hline$Z$ & seafloor depth $[\mathrm{m}]$ & \\
\hline$Z_{\mathrm{p}}$ & compensation depth $[\mathrm{m}]$ & \\
\hline$\alpha$ & coefficient of thermal expansion $\left[\mathrm{K}^{-1}\right]$ & $3.1 \times 10^{-5}$ \\
\hline$\beta$ & coefficient of depletion density reduction & 0.06 \\
\hline$\rho_{\mathrm{c}}$ & crustal density $\left[\mathrm{kg} \mathrm{m}^{-3}\right]$ & 2800 \\
\hline$\rho_{\mathrm{m}}$ & reference mantle density $\left[\mathrm{kg} \mathrm{m}^{-3}\right]$ & 3330 \\
\hline$\Delta \rho_{\mathrm{cw}}$ & crust-water density contrast $\left[\mathrm{kg} \mathrm{m}^{-3}\right]$ & 1770 \\
\hline$\Delta \rho_{\mathrm{m}}$ & mantle density anomaly $\left[\mathrm{kg} \mathrm{m}^{-3}\right]$ & \\
\hline$\Delta \rho_{\mathrm{mc}}$ & mantle-crust density contrast $\left[\mathrm{kg} \mathrm{m}^{-3}\right]$ & 530 \\
\hline$\Delta \rho_{\mathrm{mw}}$ & mantle-water density contrast $\left[\mathrm{kg} \mathrm{m}^{-3}\right]$ & 2300 \\
\hline
\end{tabular}

a $A_{\mathrm{c}}$ is the cross-sectional area of the excess crust (in excess of $5.6 \mathrm{~km}$ ), and $A_{\mathrm{s}}$ is the cross-sectional area of the swell topography after removing the crustal support (i.e. the area comprised between the thick solid and dashed lines in Fig. 5a, east of $\left.95^{\circ} 30^{\prime} \mathrm{W}\right) . A_{\mathrm{c}}$ and $A_{\mathrm{s}}$ are measured along the ridge, i.e. perpendicular to the spreading direction, assuming symmetry about the $90^{\circ} 50^{\prime} \mathrm{W}$ FZ. 
to mantle Bouguer anomaly (MBA) using standard procedures (e.g. [31]) in order to isolate the gravity signature of the subsurface density structure. From the FAA we subtracted the contributions of the seafloor topography and the Moho interface [32] assuming a $6 \mathrm{~km}$ thick, constantdensity crust (see Table 1 for density contrasts). The resulting MBA (Fig. 5c) shows an eastward decrease of $\sim 70 \mathrm{mGal}$ along the GSC, arising from variations in crustal thickness and/or mantle density (e.g. [31]).

Since we have independent seismic constraints on crustal thickness variations, we can estimate their contribution to the MBA. We calculated a residual MBA (RMBA) by subtracting from the FAA the gravity contributions of the seafloor and Moho interfaces assuming a constant-density crust with thickness varying according to the smooth crustal model of Fig. 5b. We did not correct for the lithospheric cooling effect (e.g. [33]) because our analysis is restricted to the zero-age, along-axis gravity anomalies. If all of the gravity variations were caused by variations in seafloor depth and crustal thickness, then the RMBA would be near zero. However, the RMBA (Fig. $5 c)$ becomes increasingly negative to the east, reaching a minimum of $\sim-25 \mathrm{mGal}$ at $92^{\circ} 15^{\prime} \mathrm{N}$, the intersection between the GSC and the WDL. Therefore, on average, east of $94^{\circ} \mathrm{W}$ crustal thickening accounts for $60 \pm 10 \%$ of the observed MBA. The negative RMBA is yet further evidence for substantial variation in mantle density, with lower mantle densities beneath the ridge near the hotspot.

The previous calculations are made with the assumption that no significant changes in crustal density occur along the GSC. The large variations in morphology along the GSC suggest the presence of significant variability in the thermal (i.e. density) structure of the axial crust. We calculated the gravitational effect of an $8 \mathrm{~km}$ wide, low-density, high-temperature axial crustal zone [34] with a progressive density decrease between $97^{\circ} \mathrm{W}$ and $91^{\circ} \mathrm{W}$ corresponding to a temperature increase of $500^{\circ} \mathrm{C}$ (a maximum estimate for the difference in average axial crustal temperature beneath a slowspreading ridge without a steady-state crustal magma chamber, and a fast-spreading ridge with a steady-state crustal magma chamber [35]). We find the effects of this structure to be small, with a maximum contribution of 5-7 $\mathrm{mGal}$ near $91^{\circ} \mathrm{W}$.

\subsection{Mantle density anomaly}

The previous analysis of topography and gravity data shows that the variation in crustal thickness along the GSC is an important, but not the only, source of support for the Galápagos swell. Variations in mantle density are also required. To determine the mantle density structure beneath the GSC we assume local isostatic equilibrium along the ridge as a combination of crustal Airy isostasy and Pratt isostasy within the mantle. The variation in mantle density $\Delta \rho_{\mathrm{m}}$ along the GSC can be inferred from a mass balance as (see Table 1 for definitions):

$$
\Delta \rho_{\mathrm{m}}=\frac{\Delta \rho_{\mathrm{mc}} \cdot \Delta C-\Delta \rho_{\mathrm{mw}} \cdot \Delta H}{Z_{\mathrm{p}}-Z-C}
$$

The only unconstrained parameter in Eq. 2 is $Z_{\mathrm{p}}$, an effective compensation depth above which we assume all the density anomalies are confined. Fig. $5 \mathrm{~d}$ shows the variations in mantle density derived from Eq. 2 for several values of $Z_{\mathrm{p}}$. If the density anomalies are shallow $\left(Z_{\mathrm{p}}=50 \mathrm{~km}\right)$, the magnitude of the density decrease east of $95^{\circ} \mathrm{W}$ is $\sim 10 \mathrm{~kg} \mathrm{~m}^{-3}$, with a maximum amplitude of $\sim 19 \mathrm{~kg} \mathrm{~m}^{-3}$ at $92^{\circ} 15^{\prime} \mathrm{N}$, the intersection between the GSC and the WDL. For $Z_{\mathrm{p}}=100 \mathrm{~km}$, the density anomaly east of $95^{\circ} \mathrm{W}$ is $\sim 5 \mathrm{~kg} \mathrm{~m}^{-3}$, with a maximum amplitude of $\sim 8 \mathrm{~kg} \mathrm{~m}^{-3}$ at $92^{\circ} 15^{\prime} \mathrm{N}$. For deeper compensation depths the maximum density anomaly is less than $5 \mathrm{~kg} \mathrm{~m}^{-3}$.

To constrain $Z_{\mathrm{p}}$ we calculate the gravity contribution of each of the density structures displayed in Fig. 5d and then compare them to the RMBA. The results (Fig. 5c) show that the gravity data are consistent with compensation depths of $50-100 \mathrm{~km}$, indicating significant mantle density reduction near the hotspot, with values of 4-8 $\mathrm{kg} \mathrm{m}^{-3}$ near $91^{\circ} 25^{\prime} \mathrm{W}$ and maximum values of $8-19 \mathrm{~kg} \mathrm{~m}^{-3}$ near the intersection of the WDL. These calculations show that shallow mantle density variations are sufficient to support the swell, 
without the need to invoke dynamic uplift unrelated to shallow density variations (e.g. [36]).

\subsection{Melting models and inferred excess temperature}

The mantle density anomalies may arise from thermal expansion and/or from compositional variations. To estimate the thermal contribution to the mantle density anomaly we assume that the eastward increase in crustal thickness along the GSC originates from temperature variations in the underlying mantle. To calculate the temperature increase required to produce the crustal thickness variations, we assume passive mantle upwelling and we integrate the melt produced along adiabatic melting paths for different mantle potential temperatures (assuming that all the melt is extracted) (e.g. [17]). We use the melting function [37] (see Table 1 for definitions):

$\frac{\mathrm{d} F}{\mathrm{~d} P}=\frac{d T /\left.d P\right|_{a d b}-d T /\left.d P\right|_{s o l}}{H_{f} / C_{p}+d T / d F}$
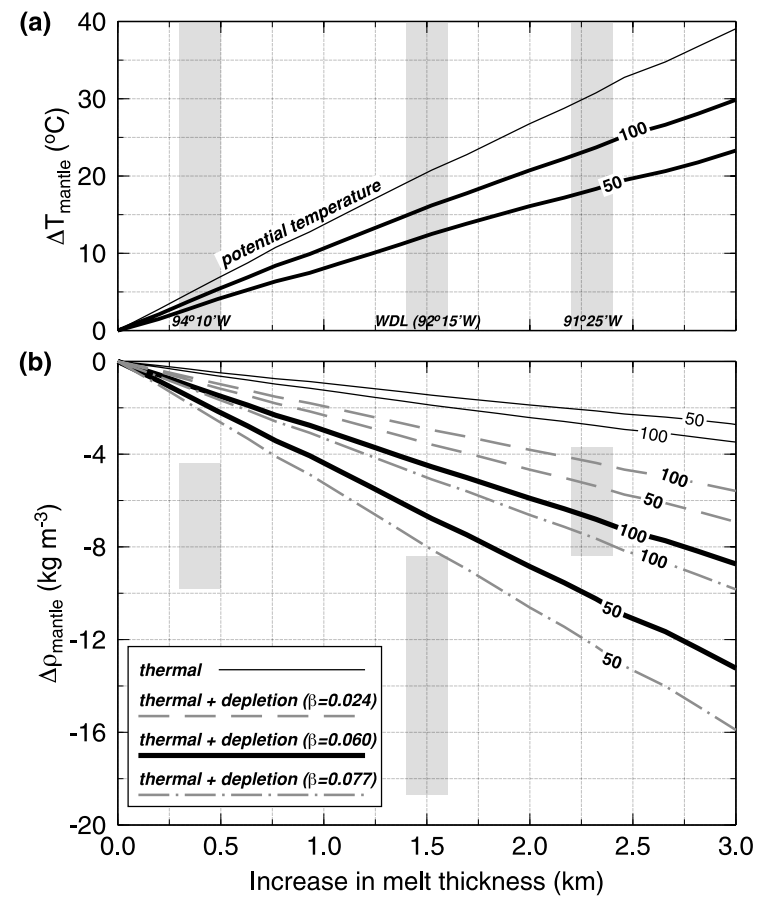

with

$\mathrm{d} T / \mathrm{d} F=\begin{array}{ll}350(1-P / 8.8) & \text { for } F<22 \% \\ 680(1-P / 8.8) & \text { for } F \geq 22 \%\end{array}$

Fig. 6a shows the relationship between increment of mantle temperature and the increase in melt thickness. The maximum observed increase

Fig. 6. (a) The thin solid line is the increase in mantle potential temperature versus increase in melt thickness derived from the melting model of Langmuir et al. [37]. For a given mantle potential temperature, Eqs. 3 and 4 were solved numerically for $P, T$ and $F$ using an explicit Runge-Kutta scheme. The melt thickness was then estimated by integrating the volumetric melt fraction along the melting path above the solidus [17]. Eq. 3 yields melt productivities of $\mathrm{d} F /$ $\mathrm{d} P=12$ and $18 \% \mathrm{GPa}^{-1}$ for $F<$ and $\geq 22 \%$, respectively (the reduction in productivity at $22 \%$ simulates the effects of exhausting clinopyroxene as a melting phase). We also explored the dependence of our results on the melt productivity function. Allowing $\mathrm{d} F / \mathrm{d} P$ to increase with $F$ [56], the increase in mantle potential temperature required to match the crustal thickness variations is a few ${ }^{\circ} \mathrm{C}$ smaller than using Eqs. 3 and 4 , indicating that our results are not significantly sensitive to the melt productivity function adopted. Because latent heat removal during melting decreases mantle temperatures above the solidus [38], the mean temperature variation present beneath the GSC should be smaller than the variation in potential temperature. We included this effect by calculating, for a given potential temperature, the temperature difference between a melting path and the adiabat without melting, averaged above the compensation depth. At the same potential temperature, shallower compensation depths therefore yield smaller mean temperature anomalies than greater compensation depths because a larger portion of the mantle contributing to the swell bathymetry is cooled by latent heat loss. This effect is illustrated with bold lines for our preferred compensation depths (labeled in $\mathrm{km}$ ). Gray bands mark the excess crustal thickness at $91^{\circ} 25^{\prime} \mathrm{W}, 92^{\circ} 15^{\prime} \mathrm{W}$ (the intersection of the WLD) and $94^{\circ} 10^{\prime} \mathrm{W}$. (b) Reduction in mantle density against increase in melt thickness derived from the melting calculations, for our preferred compensation depths (labeled in $\mathrm{km}$ ). Thin solid lines correspond to the decrease in density due to thermal expansion. Thick solid lines correspond to the decrease in density due to the combined effects of thermal expansion and melt depletion for $\beta=0.060$. Also shown by dashed and dash-dotted gray lines are the results for minimum (0.024) and maximum (0.077) estimates of $\beta$ (see text for details.) Gray bands mark the excess crustal thickness at three locations along the axis, as in (a), and the range of mantle density anomaly inferred from the isostasy model for our preferred compensation depths as illustrated in Fig. 5d. 
in crustal thickness derived $(2.3 \mathrm{~km})$ requires an increase in mantle potential temperature of $30^{\circ} \mathrm{C}$. However, the actual increase in mean mantle temperature above the compensation depth is somewhat smaller $\left(18-24^{\circ} \mathrm{C}\right.$ for $\left.Z_{\mathrm{p}}=50-100 \mathrm{~km}\right)$ due to the loss of latent heat of fusion (e.g. [38]). This result indicates that a moderate mantle thermal anomaly along the GSC is sufficient to explain the observed variation in crustal thickness.

The mantle density reduction due to the elevated temperatures and enhanced melt production can be expressed as the sum of two components: one purely thermal and a second one related to the loss of dense phases (spinel) and elements ( $\mathrm{Fe}$ with respect to $\mathrm{Mg}$ ) during melting (mantle depletion) $[11,12]$ (see Table 1 for definitions):

$\Delta \rho=-\rho_{\mathrm{m}}(\alpha \cdot \Delta T+\beta \cdot \Delta F)$

Here $\Delta F$ is the excess in average melt depletion beneath the GSC produced by the mantle temperature anomaly and $\beta$ is the coefficient of depletion buoyancy. The increase in $\mathrm{MgO} / \mathrm{FeO}$ ratio in the mantle residue for $25 \%$ melting reduces the density of the depleted mantle by $0.6 \%$ with respect to the fertile mantle [11], yielding $\beta=0.024$. If melting occurs primarily within the spinel stability zone, the consumption of spinel and clinopyroxene and the increasing $\mathrm{MgO} / \mathrm{FeO}$ leaves a residue $1.5 \%$ less dense than a fertile spinel lherzolite [11], yielding $\beta=0.060$. If significant melting occurs in the garnet stability field, the total density reduction is $2 \%$ with respect to a fertile garnet lherzolite [11], yielding a maximum estimate of $\beta=0.077$. We adopt $\beta=0.060$ as our preferred value since most of the melting beneath the GSC likely occurs above 70-90 km [39], values consistent with our preferred range of compensation depths of 50-100 $\mathrm{km}$.

Fig. $6 \mathrm{~b}$ shows that the density reduction due to thermal expansion for the temperature increment of $18-24^{\circ} \mathrm{C}$ associated with the $2.3 \mathrm{~km}$ of crustal thickening is very small, less than $-3 \mathrm{~kg} \mathrm{~m}^{-3}$. By including the effects of mantle depletion $(\beta=0.06)$, the predicted maximum density anomaly near $91^{\circ} \mathrm{W}$ is $\sim 7-10 \mathrm{~kg} \mathrm{~m}^{-3}$, while near the WDL it is $\sim 4-7 \mathrm{~kg} \mathrm{~m}^{-3}$. As reference we also show in Fig. $6 \mathrm{~b}$ the density anomalies predicted for the end-member cases of $\beta=0.024$ and $\beta=$ 0.077 . By comparing the mantle density anomalies predicted by the melting model with those required by the geophysical data (shaded boxes in Fig. 6b), we find that depletion and thermal expansion are sufficient to explain the density anomaly near $91^{\circ} \mathrm{W}$, but not beneath other sections of the GSC. This is true especially at $92^{\circ} 15^{\prime} \mathrm{W}$, where the WDL intersects the GSC. Here the melting model predicts only $\sim 4-7 \mathrm{~kg}$ $\mathrm{m}^{-3}$ of the $\sim 9-20 \mathrm{~kg} \mathrm{~m}^{-3}$ density reduction estimated from the isostasy model for our preferred compensation depths of $50-100 \mathrm{~km}$. Thus a large portion, but not all, of the GSC swell and gravity anomaly can be explained by the combined effects of an eastward thickening of the crust and associated reduction in mantle density caused by increasing temperatures and degree of melt depletion.

\section{Discussion}

\subsection{Crustal thickness variations}

The results from our seismic experiment represent the first direct measure of crustal thickness along the GSC. Taking crustal thickness as a proxy for magma supply, the seismic measurements provide important constraints on the lateral extent of the plume-related thermal anomaly along the GSC. While crustal thickening along the western GSC is very gradual, there are two distinct gradients in the pattern of crustal thickening (Fig. 5b). West of $94^{\circ} \mathrm{W}$ the crust thickens to the east by only a few hundred meters at a rate of $\sim 130 \mathrm{~m}$ per $100 \mathrm{~km}$, while most of the thickening $(\sim 2 \mathrm{~km})$ occurs east of $94^{\circ} \mathrm{W}$ at a more rapid rate $(\sim 620 \mathrm{~m}$ per $100 \mathrm{~km})$. This pattern suggests that the plume influence on magma supply at the GSC is confined primarily to within $\sim 350 \mathrm{~km}$ of where the western GSC is closest to the hot spot, consistent with the steeper geochemical gradients observed east of $94-93^{\circ} \mathrm{W}$ [22]. The relative enrichment in $\mathrm{K} / \mathrm{Ti}$ and $\mathrm{Nb} / \mathrm{Zr}$ in basalts collected east of the $95^{\circ} 30^{\prime} \mathrm{W}$ propagator with respect to samples to the west of it suggests that the propagator might be the western limit of plume-affected 
mantle [22]. Therefore, while the compositional plume anomaly may extend for $>500 \mathrm{~km}$ along the ridge, our constraints on crustal thickness suggest that the thermal anomaly is more confined, probably due to conductive cooling. These observations provide important constraints on the regional thermal structure and along-axis dispersal of plume material in the Galápagos plume-ridge system.

\subsection{Excess buoyancy}

Our results agree with the main conclusion of the previous study of the Galápagos swell by Ito and Lin [21], that is, both crustal thickening and higher temperatures near the hotspot within the shallow mantle contribute to support the swell. We find that crustal thickness variations support, on average, $52 \%$ of the depth anomaly and create $60 \%$ of the MBA. These are maximum estimates of the crustal contribution to swell topography and gravity anomaly due to our assumption of constant crustal density. Since most of the crustal thickening occurs in the lower crust (Fig. 3b), we are overestimating $\Delta \rho_{\mathrm{mc}}$ in the plume-affected section of the ridge and therefore underestimating the amplitude of the decrease in RMBA and mantle density along the GSC by $\sim 10 \%$.

Quantitatively, our measured crustal thickness variation $(2.3 \mathrm{~km})$ and inferred excess temperature $\left(30^{\circ} \mathrm{C}\right)$ are at the lower bounds of Ito and Lin's predictions of $3 \pm 1 \mathrm{~km}$ and $50 \pm 25^{\circ} \mathrm{C}$, respectively. Since Ito and Lin had no seismic constraints on crustal thickness, they explained the topography and gravity anomalies with a slightly larger crustal thickness and mantle temperature anomalies. The new constraints on crustal thickness from this study show that an additional source of buoyancy in the mantle is required to support the swell.

A plausible origin for the additional buoyancy is melt retention in the mantle [40]. If the flux of melt rising through the mantle increases with mantle porosity, then it seems logical that variations in melt retention would be positively correlated with variations in magma supply. However, we find the largest crustal thickness and inferred melt flux near $91^{\circ} 30^{\prime} \mathrm{W}$ (Fig. 5b), offset from the calculated maximum mantle density reduction near $92^{\circ} 15^{\prime} \mathrm{W}$ (Fig. 5d). This could reflect a decoupling between crustal thickness and melt flux (e.g. by ductile crustal flow [41] or along-axis melt migration at crustal and/or sub-crustal levels), or argues against melt retention as the origin of the excess buoyancy.

Another possible explanation for the additional mantle buoyancy is related to the concept that plume material from the Galápagos hotspot feeds the GSC (e.g. [22,42]). As plume material melts at the upwelling plume beneath the Galápagos Islands its density decreases due to depletion [7]. Some of this material may flow northward to the GSC and introduce buoyancy unrelated to melting beneath the GSC [18]. This hypothesis is consistent with the low ${ }^{3} \mathrm{He} /{ }^{4} \mathrm{He}$ ratio observed along the GSC that suggests that plume-affected mantle beneath the GSC has been degassed by prior melting in the upwelling plume [22], and it is also consistent with the significant depleted signature exhibited by lavas erupted in the northern Galápagos Islands and along the WDL [43]. One caveat for this scenario is that mantle depletion increases the temperature of the solidus at a given depth (e.g. [37]); therefore the variation in mantle potential temperature required to explain the along-axis crustal thickness variations would be larger than our estimate, increasing the contribution of thermal buoyancy.

A depleted mantle source for the excess buoyancy seems to contradict the observed enrichment in incompatible elements along the GSC near the hotspot $[22,42]$. While modeling the dynamics of the Galápagos plume-ridge system and its geochemical implications are beyond the scope of this paper, this apparent discrepancy could be explained by a scenario in which flow from the plume to the ridge occurs at two distinct levels. Depleted residue from the center of the plume channel would flow at shallow levels to the ridge, contributing to the excess buoyancy, while enriched material without significant prior melting from the outer zones of the plume might flow at deeper levels, contributing to the enriched, lowmelt-fraction lavas found at the GSC [22].

The maximum excess buoyancy occurs at the intersection of the GSC with the WDL, which 
was proposed to be the surface expression of channelized flow from the plume to the ridge [44]. Narrow sublithospheric channels connecting plumes and mid-ocean ridges may develop in plume-ridge systems where the ridge migrates away from the plume [45-47]. However, the inferred moderate temperature anomaly and viscosity of the Galápagos plume argues for preferentially radial, rather than focused, lateral flow of plume material [18]. In this scenario, melt associated with secondary, small-scale convection [48] or decompression during upslope flow [45] may be focused along pre-existing lithospheric fractures, enhancing locally the buoyancy by melt retention. Our data cannot discriminate between this hypothesis and the hypothesis in which hot and compositionally buoyant plume material is delivered to the GSC along the WDL. However, the striking correlation between the WDL and the excess buoyancy suggests that the WDL plays an important role in the Galápagos plume-ridge system that should be further investigated in future research.

\subsection{Buoyancy flux and crustal productivity}

Our new results on swell topography and on its crustal support allow us to place constraints on buoyancy fluxes and crustal production rates at the Galápagos plume-ridge system. The buoyancy flux of excess mass flowing away from the ridge axis is given by (see Table 1 for definitions):

$B=A_{\mathrm{s}} \cdot \Delta \rho_{\mathrm{mw}} \cdot U$

and it is the sum of thermal buoyancy $B_{\mathrm{T}}$ and the buoyancy flux caused by melt depletion $B_{\mathrm{F}}$. We compute $B_{\mathrm{F}}$ from (e.g. [13]):

$B_{\mathrm{F}}=Q_{\mathrm{ca}} \cdot \rho_{\mathrm{c}} \cdot \beta$

where $Q_{\text {ca }}$ is the volume flux of excess crustal production at the ridge axis defined as:

$Q_{\mathrm{ca}}=A_{\mathrm{c}} \cdot U$

From Eqs. 6-8 we find that $B=700 \mathrm{~kg} \mathrm{~s}^{-1}$, $B_{\mathrm{F}}=255 \mathrm{~kg} \mathrm{~s}^{-1}$ and $B_{\mathrm{T}}=445 \mathrm{~kg} \mathrm{~s}^{-1}$. These values indicate that melt depletion is important, contributing $\sim 35 \%$ of the total buoyancy $B$ at the GSC.
Our estimate of the thermal buoyancy $B_{\mathrm{T}}$ is small compared to prior estimates of $10^{3} \mathrm{~kg} \mathrm{~s}^{-1}$ without crustal thickness constraints $[47,49]$. The presence of the excess mantle buoyancy requires thermal buoyancy to be less than the above estimate. Low thermal buoyancy is consistent with our low excess temperatures along the GSC and suggests low excess temperatures and/or low volume flux arising from the Galápagos plume. Indeed, a plume temperature excess of considerably less than $100^{\circ} \mathrm{C}$ can be inferred if the lateral thermal gradient in the mantle between the GSC and the Galápagos Islands is comparable to that estimated along the GSC.

Ito et al. [18] estimated the crustal volume flux forming the Galápagos platform to be $\sim 4 \mathrm{~m}^{3}$ $\mathrm{s}^{-1}$. Therefore, considering the excess volume flux at the GSC given by Eq. $8\left(Q_{\mathrm{ca}}=1.5 \mathrm{~m}^{3}\right.$ $\mathrm{s}^{-1}$ ), the total crustal volume flux of the Galápagos plume is $\sim 5.5 \mathrm{~m}^{3} \mathrm{~s}^{-1}$. This value is surprisingly high given the moderate buoyancy flux and excess temperature. While the Galápagos crustal volume flux is $\sim 20 \%$ smaller than that of the Icelandic plume $\left(7 \mathrm{~m}^{3} \mathrm{~s}^{-1}\right)$ [50], it is comparable to that of the Hawaiian plume $\left(5 \mathrm{~m}^{3} \mathrm{~s}^{-1}\right)$ [51]. Despite their difference in excess plume temperature, the similar crustal volume fluxes of the Galápagos and Hawaiian plumes are likely due to the differences in lithospheric thickness. By considering the combined crustal production of the Galápagos plume and seafloor spreading at the GSC, we find that the crustal productivity of the Galápagos plume-ridge system is $\sim 15.7 \mathrm{~m}^{3} \mathrm{~s}^{-1}$, very similar to the $\sim 16 \mathrm{~m}^{3} \mathrm{~s}^{-1}$ of the IcelandMAR system [50]. This result indicates that the three-fold increase in plate velocities at the Galápagos plume-ridge system offsets the larger island volume and wider along-axis plume influence of the Iceland-MAR system.

\section{Conclusions}

The integrated modeling and interpretation of bathymetry, gravity and seismic data presented in this study places constraints on the compensation mechanism of the Galápagos swell, allowing us to quantify the roles of crustal thickness, mantle 
temperature and mantle depletion in supporting the Galápagos hotspot swell. The main conclusions of our study are as follows:

1. Modeling of wide-angle refraction and multichannel seismic data along the western GSC between $97^{\circ} \mathrm{W}$ and $91^{\circ} 25^{\prime} \mathrm{W}$ indicates that the crust thickens by $\sim 2.3 \mathrm{~km}$ as the Galápagos hotspot is approached from the west.

2. The eastward increase in crustal thickness is accompanied by a decrease in axial depth of $1800 \mathrm{~m}(60 \%$ of which is due to changes in axial morphology) and a decrease in MBA of $70 \mathrm{mGal}$. Crustal thickness variations explain $52 \%$ of the depth anomaly and $60 \%$ of the MBA. The remaining anomalies require the presence of low mantle densities beneath the GSC near the hotspot, constrained to be within the uppermost mantle (above $50-100 \mathrm{~km}$ depth).

3. Assuming passive upwelling beneath the GSC, we find that the crustal thickness variations are consistent with an eastward increase in mantle potential temperature of $30^{\circ} \mathrm{C}$.

4. The density anomaly produced by thermal expansion and mantle depletion beneath the ridge is smaller than that estimated from the geophysical data, with the largest discrepancies found at the intersection of the GSC and the WDL. These discrepancies imply the existence of an additional compositionally buoyant source supporting the Galápagos swell. Possible origins of this anomaly are melt retained in the mantle as well as mantle depleted by melting in the upwelling plume beneath the Galápagos Islands that is then transported to the GSC.

5. Depletion and thermal buoyancy accounts for $\sim 35 \%$ and $\sim 65 \%$, respectively, of our estimate for the total buoyancy flux of $700 \mathrm{~kg}$ $\mathrm{s}^{-1}$. While buoyancy flux is moderate compared to prior estimates of other hotspots, the rate of crustal production of the Galápagos plume is comparable to that of the Iceland and Hawaii mantle plumes, and the crustal productivity of the Galápagos plume-ridge system is also comparable to that of the Iceland-MAR system.

\section{Acknowledgements}

This study was supported by the National Science Foundation Grant OCE-9819117 to the Woods Hole Oceanographic Institution and OCE-9818632 to the University of Hawaii. We thank Captain Mark Landow, Science Officer Chris Leidhold, and the crew of the R/V Maurice Ewing Leg 00-04 for their help in the data acquisition. We also thank Ecuadorian authorities for granting us permit to work within Ecuador's exclusive economic zone, and the officers of the Galápagos National Park and Charles Darwin Research Station for facilitating our work within the limits of the Galápagos National Park. We are grateful to the WHOI OBS Group, namely, J. Bailey, T. Bolmer, D. DuBois and R. Handy for their technical support; and to all the participants of the G-PRIME cruise for their assistance in the fieldwork. M. Behn helped with the gravity data reduction and calculations. G. Hirth, P. Kelemen and J. Lin are acknowledged for suggestions and comments on various aspects of this study. The paper benefited from reviews by I. Grevemeyer, Y. Shen and two anonymous reviewers. The GMT software [52] was used in the preparation of this manuscript. Contribution numbers WHOI-10758 and SOEST-5999.[SK]

\section{Appendix}

To estimate the uncertainty of the velocity models (Fig. 3c), we generated a large number of crustal models by adding random velocity perturbations at each depth node to our preferred models (imposing positive velocity gradients with depth, and that the randomized velocity values were within reasonable bounds according to the depth). We then calculated the travel times predicted by the random models. The velocity uncertainties were then estimated as the standard deviation of all of the random models that provided reasonable fits to the data. Our velocity error estimates indicate that the MCS TWTT Moho picks can be converted to depth with an accuracy of $\pm 150 \mathrm{~m}$.

The uncertainty of the crustal thickness esti- 
mates is mostly controlled by the tradeoff between crustal thickness and lower crustal velocity. We explored this ambiguity in our solutions by modeling the travel times with velocity models that included all possible combinations of lower crustal velocities ranging between 6.9 and $7.4 \mathrm{~km} \mathrm{~s}^{-1}$, and crustal thicknesses within $\pm 1 \mathrm{~km}$ of our preferred solution (the velocity structure of the upper and middle crust was our preferred solution in all cases). The models that yield reasonable fits indicate that the velocity-depth ambiguity introduces an uncertainty of $0.2-0.3 \mathrm{~km}$ to the wide-angle crustal thickness estimates (Fig. 3b).

\section{References}

[1] S.T. Crough, Hotspot swells, Annu. Rev. Earth Planet. Sci. 11 (1983) 165-193.

[2] M.K. McNutt, L. Shure, Estimating the compensation depth of the Hawaiian swell with linear filters, J. Geophys. Res. 91 (1986) 13915-13923.

[3] R.P. Von Herzen, M.J. Cordery, R.S. Detrick, C. Fang, Heat flow and the thermal origin of hot spot swells: the Hawaiian swell revisited, J. Geophys. Res. 94 (1989) 13783-13799.

[4] R.C. Courtney, R.S. White, Anomalous heat flow and geoid across the Cape Verde Rise: evidence for dynamic support from a thermal plume in the mantle, Geophys. J. R. Astron. Soc. 87 (1986) 815-867.

[5] R.S. Detrick, R.P. Von Herzen, B. Parsons, D.T. Sandwell, M.E. Dougherty, Heat flow observations on the Bermuda Rise and thermal models of midplate swells, J. Geophys. Res. 91 (1986) 3701-3723.

[6] M.K. McNutt, A. Bonneville, A shallow, chemical origin for the Marquesas swell, Geochem. Geophys. Geosyst. 1,

[7] J. Phipps Morgan, W.J. Morgan, E. Price, Hotspot melting generates both hotspot volcanism and a hotspot swell?, J. Geophys. Res. 100 (1995) 8045-8062.

[8] R.N. Harris, R.P. Von Herzen, M.K. McNutt, G. Garven, K.A. Jordahl, Submarine hydrogeology of the Hawaiian archipelagic apron 1. Heat flow patterns north of Oahu and Maro reef, J. Geophys. Res. 105 (2000) 21353-21369.

[9] G. Laske, J. Phipps Morgan, J.A. Orcutt, First results from the Hawaiian SWELL Pilot Experiment, Geophys. Res. Lett. 26 (1999) 3397-3400.

[10] D. Zhao, Seismic structure and origin of hotspots and mantle plumes, Earth Planet. Sci. Lett. 192 (2001) 251265.

[11] E.R. Oxburgh, E.M. Parmentier, Compositional and density stratification in oceanic lithosphere - causes and consequences, J. Geol. Soc. Lond. 133 (1977) 343-355.

[12] T.H. Jordan, Mineralogies, densities and seismic velocities of garnet lherzolites and their geophysical implications, in: F.R. Boyd, H.O.A. Meyer (Eds.), The Mantle Sample: Inclusions in Kimberlites and Other Volcanics 2, AGU, Washington, DC, 1979, pp. 1-14.

[13] N.M. Ribe, U.R. Christensen, The dynamical origin of Hawaiian volcanism, Earth Planet. Sci. Lett. 171 (1999) 517-531.

[14] R. Katzman, L. Zhao, T.H. Jordan, High-resolution, twodimensional vertical tomography of the central Pacific mantle using $S c S$ reverberations and frequency-dependent travel times, J. Geophys. Res. 103 (1998) 17933-17971.

[15] D.W. Caress, M.K. McNutt, R.S. Detrick, J.C. Mutter, Seismic imaging of hotspot-related crustal underplating beneath the Marquesas Islands, Nature 373 (1995) 600603.

[16] A.B. Watts, U.S. ten Brink, P. Buhl, T.M. Brocher, A multichannel seismic study of lithospheric flexure across the Hawaiian-Emperor seamount chain, Nature 315 (1985) 105-111.

[17] D. McKenzie, The generation and compaction of partially molten rock, J. Petrol. 25 (1984) 713-765.

[18] G. Ito, J. Lin, C.W. Gable, Interaction of mantle plumes and migrating mid-ocean ridges; implications for the Galapagos plume-ridge system, J. Geophys. Res. 102 (1997) 15403-15417.

[19] C. DeMets, R.G. Gordon, D.F. Argus, S. Stein, Effect of recent revisions to the geomagnetic reversal time scale on estimates of current plate motions, Geophys. Res. Lett. 21 (1994) 2191-2194.

[20] J.P. Canales, J.J. Dañobeitia, R.S. Detrick, E.E.E. Hooft, R. Bartolomé, D.F. Naar, Variations in axial morphology along the Galápagos spreading center and the influence of the Galápagos hotspot, J. Geophys. Res. 102 (1997) 27341-27354.

[21] G. Ito, J. Lin, Mantle temperature anomalies along the present and paleoaxes of the Galápagos Spreading Center as inferred from gravity analyses, J. Geophys. Res. 100 (1995) 3733-3745.

[22] R.S. Detrick, J.M. Sinton, G. Ito, J.P. Canales, M. Behn, T. Blacic, B. Cushman, J.E. Dixon, D.W. Graham, J. Mahoney, Correlated geophysical, geochemical and volcanological manifestations of plume-ridge interaction along the Galapagos Spreading Center, Geochem. Geophys. Geosyst. (2002) in press.

[23] J.M. Sinton, R.S. Detrick, Seismic and Petrologic Investigation of the Effects of Plume-Ridge Interaction at the Galapagos Spreading Center, Woods Hole Oceanogr. Inst., Woods Hole, MA, 2000, 136 pp.

[24] E.E.E. Hooft, R.S. Detrick, D.R. Toomey, J.A. Collins, J. Lin, Crustal and upper mantle structure along three contrasting spreading segments of the Mid-Atlantic Ridge, $33.5^{\circ}-35^{\circ} \mathrm{N}$, J. Geophys. Res. 105 (2000) 8205-8226.

[25] J.P. Canales, R.S. Detrick, J. Lin, J.A. Collins, D.R. Toomey, Crustal and upper mantle seismic structure beneath the rift mountains and across a nontransform offset at the Mid-Atlantic Ridge $\left(35^{\circ} \mathrm{N}\right)$, J. Geophys. Res. 105 (2000) 2699-2719. 
[26] C.A. Zelt, R.B. Smith, Seismic traveltime inversion for 2-D crustal velocity structure, Geophys. J. Int. 108 (1992) 16-34.

[27] I. Grevemeyer, W. Weigel, C. Jennrich, Structure and ageing of oceanic crust at $14^{\circ} \mathrm{S}$ on the East Pacific Rise, Geophys. J. Int. 135 (1998) 573-584.

[28] J.S. McClain, C.A. Atallah, Thickening of the oceanic crust with age, Geology 14 (1986) 574-576.

[29] J. Phipps Morgan, E.M. Parmentier, J. Lin, Mechanisms for the origin of mid-ocean ridge axial topography: implications for the thermal and mechanical structure of accreting plate boundaries, J. Geophys. Res. 92 (1987) 12823-12836.

[30] M.A. Eberle, D.W. Forsyth, An alternative, dynamic model of the axial topographic high at fast spreading ridges, J. Geophys. Res. 103 (1998) 12309-12320.

[31] B.-Y. Kuo, D.W. Forsyth, Gravity anomalies of the ridge-transform system in the South Atlantic between $31^{\circ}$ and $34.5^{\circ} \mathrm{S}$ : Upwelling centers and variations in crustal thickness, Mar. Geophys. Res. 10 (1988) 205-232.

[32] R.L. Parker, The rapid calculation of potential anomalies, Geophys. J. R. Astron. Soc. 31 (1972) 447-455.

[33] J. Phipps Morgan, D.W. Forsyth, Three-dimensional flow and temperature perturbations due to a transform offset: Effects on oceanic crustal and upper mantle structure, J. Geophys. Res. 93 (1988) 2955-2966.

[34] R.A. Dunn, D.R. Toomey, S.C. Solomon, Three-dimensional seismic structure and physical properties of the crust and shallow mantle beneath the East Pacific Rise at $9^{\circ} 30^{\prime} \mathrm{N}$, J. Geophys. Res. 105 (2000) 23463-23478.

[35] T.J. Henstock, A.W. Woods, R.S. White, The accretion of oceanic crust by episodic sill intrusion, J. Geophys. Res. 98 (1993) 4143-4161.

[36] M.M. Yale, J. Phipps Morgan, Asthenosphere flow model of hotspot-ridge interactions: a comparison of Iceland and Kerguelen, Earth Planet. Sci. Lett. 161 (1998) 45-56.

[37] C.H. Langmuir, E.M. Klein, T. Plank, Petrological systematics of mid-ocean ridge basalts: Constraints on melt generation beneath ocean ridges, in: J. Phipps Morgan, D.K. Blackman, J.M. Sinton (Eds.), Mantle Flow and Melt Generation at Mid-Ocean Ridges, Geophys. Monogr. Ser. 71, AGU, Washington, DC, 1992, pp. 183-280.

[38] D. McKenzie, M.J. Bickle, The volume and composition of melt generated by extension of the lithosphere, J. Petrol. 29 (1988) 625-679.

[39] Y. Shen, D.W. Forsyth, Geochemical constraints on initial and final depths of melting beneath mid-ocean ridges, J. Geophys. Res. 100 (1995) 2211-2237.

[40] K. Jha, E.M. Parmentier, J. Phipps Morgan, The role of mantle-depletion and melt retention buoyancy in spread- ing-center segmentation, Earth Planet. Sci. Lett. 125 (1994) 221-234.

[41] R.E. Bell, W.R. Buck, Crustal control of ridge segmentation inferred from observations of the Reykjanes Ridge, Nature 357 (1992) 583-586.

[42] J.-G. Schilling, R.H. Kingsley, J.D. Devine, Galapagos hot spot-spreading center system 1 . Spatial petrological and geochemical variations $\left(83^{\circ} \mathrm{W}-101^{\circ} \mathrm{W}\right)$, J. Geophys. Res. 87 (1982) 5593-5610.

[43] K.S. Harpp, W.M. White, Tracing a mantle plume: isotopic and trace element variations of Galápagos seamounts, Geochem. Geophys. Geosyst. 2,

[44] W.J. Morgan, Rodriguez, Darwin, Amsterdam,.., a second type of hotspot island, J. Geophys. Res. 83 (1978) 5355-5360.

[45] N.H. Sleep, Lateral flow of hot plume material ponded at sublithospheric depths, J. Geophys. Res. 101 (1996) 28065-28083.

[46] N.M. Ribe, The dynamics of plume-ridge interaction 2. Off-ridge plumes, J. Geophys. Res. 101 (1996) 16195 16204.

[47] J.-G. Schilling, Fluxes and excess temperatures of mantle plumes inferred from their interaction with migrating mantle plumes, Nature 352 (1991) 397-403.

[48] W.B. Moore, G. Schubert, P. Tackley, Three-dimensional simulations of plume-lithosphere interaction at the Hawaiian swell, Science 279 (1998) 1008-1011.

[49] N.H. Sleep, Hotspots and mantle plumes: some phenomenology, J. Geophys. Res. 95 (1990) 6715-6736.

[50] G. Ito, J. Lin, C.W. Gable, Dynamics of mantle flow and melting at a ridge-centered hotspot: Iceland and the MidAtlantic Ridge, Earth Planet. Sci. Lett. 144 (1996) 53-74.

[51] S. Watson, D. McKenzie, Melt generation by plumes: a study of Hawaiian volcanism, J. Petrol. 32 (1991) 501537.

[52] P. Wessel, W.H.F. Smith, New version of the generic mapping tools released, EOS Trans. AGU 76 (1995) 329.

[53] W.H.F. Smith, D.T. Sandwell, Global seafloor topography from satellite altimetry and ship depth soundings, Science 277 (1997) 1957-1962.

[54] M.D. Kurz, D.J. Geist, Dynamics of the Galapagos hotspot from helium isotope geochemistry, Geochim. Cosmochim. Acta 63 (1999) 4139-4156.

[55] A.E. Gripp, R.G. Gordon, Current plate velocities relative to the hotspots incorporating the NUVEL-1 global plate motion model, Geophys. Res. Lett. 17 (1990) 1109 1112.

[56] P.D. Asimow, M.M. Hirschmann, E.M. Stolper, An analysis of variations in isentropic melt productivity, Phil. Trans. R. Soc. Lond. A355 (1997) 255-281. 